\title{
Elderly victims of violence: family assessment through the Calgary model
}

\author{
Idosos vítimas de violência: avaliação da família \\ por meio do modelo Calgary
}

Víctima antigua de violencia: evaluación la familia

a través del modelo Calgary

\author{
Miriam Fernanda Sanches Alarcon ${ }^{\mathrm{a}}$ \\ Bruna Carvalho Cardoso ${ }^{b}$ \\ Caroline Borges Alac \\ Daniela Garcia Damaceno ${ }^{a}$ \\ Viviane Boacnin Yoneda Sponchiado ${ }^{d}$ \\ Maria José Sanches Marin ${ }^{a, c}$
}

\begin{abstract}
How to cite this article: Alarcon MFS, Cardoso BC, Ala CB, Damaceno DG, Sponchiado VBY, Marin MJS. Elderly victims of violence: family assessment through the Calgary model. Rev Gaúcha Enferm. 2022;43:e20200218. doi: https://doi.org/10.1590/19831447.2022.20200218
\end{abstract}

a Universidade Estadual Paulista "Júlio de Mesquita Filho" (UNESP), Botucatu, São Paulo, Brasil.

b Pesquisador autônomo. Marília, SP, Brasil.

(Faculdade de Medicina de Marilia (FAMEMA) Marilia, São Paulo, Brasil.

d Delegacia de Defesa da Mulher. Marília, São Paulo Brasil.

\section{ABSTRACT}

Objective: To understand the structure, development, and functionality of the family of the elderly victim of violence.

Method: Descriptive research with a qualitative approach, based on the Calgary Family Assessment Model. Four elderly people who suffered violence and their family members were assessed at home, from October to November 2019. Data analysis was based on the genogram and ecomap, as proposed in the model.

Results: It was found that the members of the four families had low schooling and financial difficulties. As for the social support network, the neighbors, the health unit and the Church stood out. The members of each family nucleus expressed feelings of fear, insecurity, anger, nervousness, sadness and impotence, resulting from the conflict between the couple.

Final considerations: In the assessed families, weaknesses and potentialities in the structure, development and functioning are highlighted, which must be considered in the elaboration of the care plan.

Keywords: Aged. Violence. Aging.

\section{RESUMO}

Objetivo: Compreender a estrutura, o desenvolvimento e a funcionalidade da família da pessoa idosa vítima de violência.

Método: Pesquisa descritiva e de abordagem qualitativa, pautada no Modelo Calgary de Avaliação Familiar. Avaliaram-se, no próprio domicílio, quatro idosos que sofreram violência e os respectivos familiares, no período de outubro a novembro de 2019. A análise dos dados ocorreu com base no genograma e ecomapa, conforme proposto no modelo.

Resultados: Verificou-se que os integrantes das quatro famílias apresentaram baixa escolaridade e dificuldades financeiras. Quanto à rede de suporte social, destacaram-se os vizinhos, a unidade de saúde e a Igreja. Os membros de cada núcleo familiar manifestaram sentimentos de medo, insegurança, raiva, nervosismo, tristeza e impotência, decorrentes do conflito entre o casal.

Considerações finais: Destaca-se, nas famílias avaliadas, fragilidades e potencialidades na estrutura, no desenvolvimento e no funcionamento, que devem ser consideradas na elaboração do plano de cuidados.

Palavras-chave: Idoso. Violência. Envelhecimento.

\section{RESUMEN}

Objetivo: Comprender la estructura, desarrollo y funcionalidad de la familia del anciano víctima de violencia

Método: Investigación descriptiva con enfoque cualitativo, basada en el Modelo de Evaluación de la Familia de Calgary. Cuatro ancianos que sufrieron violencia y sus familiares fueron evaluados en su domicilio, de octubre a noviembre de 2019. El análisis de los datos se basó en el genograma y ecomapa, como se propone en el modelo.

Resultados: Se encontró que los miembros de las cuatro familias tenían baja escolaridad y dificultades económicas. En cuanto a la red de apoyo social, destacaron los vecinos, la unidad de salud y la Iglesia. Los miembros de cada núcleo familiar expresaron sentimientos de miedo, inseguridad, enfado, nerviosismo, tristeza e impotencia, resultado del conflicto entre la pareja.

Consideraciones finales: En las familias evaluadas se destacan debilidades y potencialidades en la estructura, desarrollo y funcionamiento, que deben ser consideradas en la elaboración del plan de cuidados.

Palabras clave: Anciano. Violencia. Envejecimiento. 


\section{口INTRODUCTION}

In Brazil, demographic aging, a phenomenon that deals with the increase of elderly people (over 60 years) in relation to the general population, has resulted in situations such as violence against the elderly people, a universal event present in all socioeconomic classes, regardless ethnicity and/or religion ${ }^{(1)}$.

The different causes that generate violence against the elderly people create a challenge to public health in relation to control and prevention actions, making necessary intervention and reflection on this subject, as violence can generate serious effects on the health of the elderly, leading to psychological, financial, social problems and even to disability or death(2).

It is important to emphasize that the main causes of violence against the elderly can be related to the use of alcohol, the physical proximity between aggressor and victim, financial dependence and the relationship of violence throughout life. A research conducted in emergency services in the Federal District, in 24 capitals and 11 municipalities, found that the main types of violence identified among the elderly are: physical violence (69.3\%), followed by negligence (24.0\%) and psychological and moral violence (18.5\%), being commonly practiced by children (22.4\%) $)^{(3)}$.

The family is seen as the main support network, with or without blood ties, it is also the person's first nucleus of social contact, considered the structural basis for the construction of the being, which takes for a lifetime, even that over time, it has a great possibility of constituting a new arrangement and structure for the family itself( ${ }^{(4)}$.

For families, caring for the elderly person involves continuing the relationship they experienced in the past, often through complex and conflicting relationships between the members. Thus, it is common for aggression to the elderly to occur within the family context, in which the aggressor does not perceive himself committing arbitrariness, especially when he lived in a violent context ${ }^{(5)}$.

It is considered the need for intervention in this reality and, therefore, the Calgary Family Assessment Model (CFAM) can be an important assistance instrument, as it allows understanding the structural constitution (composition of members), the development of bonds and relationships and the functionality of individuals (family roles), as well as the identification of strengths and weaknesses, with a view to proposing intervention measures ${ }^{(4)}$.

The Calgary Family Assessment and Intervention Model is designed both for the study of families of people with acute or chronic illnesses and for different situations. Through it, it is possible to detect risk factors existing in the family, through instruments such as ecomap and genogram; and program interventions to improve quality of life, as needed ${ }^{(4)}$. Thus, it is believed that the use of this model in families of elderly victims of violence can help to broaden the understanding of the context of these people's lives and lead to possible interventions.

In view of the presented considerations, it was formulated the research question: what is the structure, development and family functioning of the elderly person who suffers violence? Thus, the objective was to understand the structure, development, and functionality of the family of the elderly victim of violence.

\section{METHODS}

This research is characterized as descriptive and with a qualitative approach, aiming to understand the social relationships and experience, in the search to implement interventions with the family of elderly victims of violence( ${ }^{(6)}$.

This is an excerpt of the research and intervention project entitled: "Elderly victim of violence: the interface between health care, legal assistance and social assistance", which has been taking place in a medium-sized countryside municipality of the state of São Paulo, Brazil, through a multidisciplinary team. Contact with the families occurred through the referral of professionals from the police station, who work in conjunction with the research team that includes nurses, psychologist, physiotherapist, and psychiatrist. It was established as a cut-off point for this study the occurrence reports of violence against the elderly in September 2019. As inclusion criteria, the following were listed: having a member over 60 years old who suffered violence, residing in the municipality of study. As exclusion criteria, any family member who presented aggressive behavior or offered a risk to the researchers, having suffered violence outside the family context, according to the guidance of the professionals at the police station. In view of this, four families were assigned to the researchers.

The families'assessments took place at the victims'homes, from October to November 2019, which were previously scheduled according to the availability of the participants, including the elderly person who suffered violence and the family members with whom contact was possible. The researchers carried out three visits to each family to learn about the reality of housing, sanitation and better understand the relationships, life behaviors and violence between family members. Interventions were performed as the needs were detected. 
For assessment and intervention with families, it was used as an instrument the Calgary Family Assessment Model (CFAM), which is organized into three categories: structural, development and functional. The structural category examines the family structure, that is, the members who belong to the family and their bond in the family context and with external people, through the construction of the genogram and ecomap. In this structure, three aspects are relevant for the analysis: internal structure (family composition, gender, sexual orientation, birth order, subsystems and limits, external structure (extended family and broader systems) and the family context (ethnicity, race, social class, religion and environment) $)^{(7)}$.

The genogram is the elaboration of the family tree, its purpose is to quickly obtain a large amount of information about a family and a view of potential problems, with the main objective of assisting in the assessment, planning and intervention in the family context, clearly recognizing the members. In the construction, there are standardized codes and symbols that graphically present at least three generations of the family. Men are represented by squares and women by circles. The ecomap represents the family and the relationships with the community, services and the members themselves, recognizing the means and social support used by the family. The blood members of the family are represented inside the circle and the remaining population appears in outer circles. There are also lines that indicate the connections between internal and external members ${ }^{(7)}$.

For composition of the genogram and ecomap of this research, it was used the Corel Draw software for the graphic construction of family relationships that allows the visualization of family structure, dynamics, and functionality.

The development category deals with the progression and transformation of the family in focus, in which history, growth, birth and death are studied. In the functional category, family members and their interactions with other internal members are studied. Two aspects are explored at this moment: the instrumental functioning related to everyday life, functions and daily activities; and expressive functioning, referring to elements such as communication, problem solving and adversities, beliefs, rules, among others ${ }^{(7)}$.

The study was submitted to the Human Research Ethics Committee of the proposing institution, according to the Certificate of Presentation for Ethical Review 73664417.1.0000.5413. The free and informed consent form was signed by the members of each family nucleus. To ensure anonymity, the names were fictitious, but the real first initial letter remained.

\section{RESULTS}

When considering the assessment of the four families, in accordance with the CFAM, which includes the structural, development and functional categories, the synthesis of the assessments carried out in each of the four family nucleus, each followed by the genogram and ecomap.

Family 1 is composed by the elderly couple who lived in the same home. Célia, 69 years old, housewife, married for 51 years to Leandro, 73 years old, retired, both with incomplete elementary education, five children, and only one daughter lived close to them. The couple's monthly income was three minimum wages, from Leandro's retirement, and they lived in their own house. Célia reported violence against her husband due to the threat of death and for using profanity to verbally attack her. One of the couple's biggest conflicts was because Leandro liked to drink at lunchtime and, according to Célia, he had an altered and aggressive behavior. Leandro said he felt very angry and impotence in the face of the situation, that he couldn't stand his wife calling him attention for drinking a can of beer, that he was expelled from the house twice and that, if this fact was repeated, would leave definitely. However, she was worried about this, as the income was not enough to keep the rent on another house. Celia also claimed that she only stayed with Leandro because she depended on his income.

Célia reported feeling overwhelmed with household chores. For Leandro, dedication to the house was exhausting, even seeming like a disease. The relationship with her daughter was also conflicting, as, according to Célia, she interfered in the couple's relationship. With the other children, the couple had a good relationship, however, they had little contact with them, but they tried to alleviate conflicts over the phone.

Both were hypertensive, but only Célia used antihypertensive drugs (metoprolol and hydrochlorothiazide), reported profound sadness, attended the Basic Health Unit $(\mathrm{BHU})$, attended church three times a week and claimed to have a good relationship with neighbors. The husband, on the other hand, in addition to hypertension, had gout, but did not attend the BHU and refused to take care of his own health, even in pain, refused to accompany her to church and the bond with neighbors was weak, due to the death of the main friends over time. Family 1, represented in Figure 1, shows the structure of Célia's Family.

In Family 2, the elderly couple was interviewed. Maria Rita, a 69-year-old housewife, received sick pay, married to Adelmo,65, unemployed. They lived in their own house, 


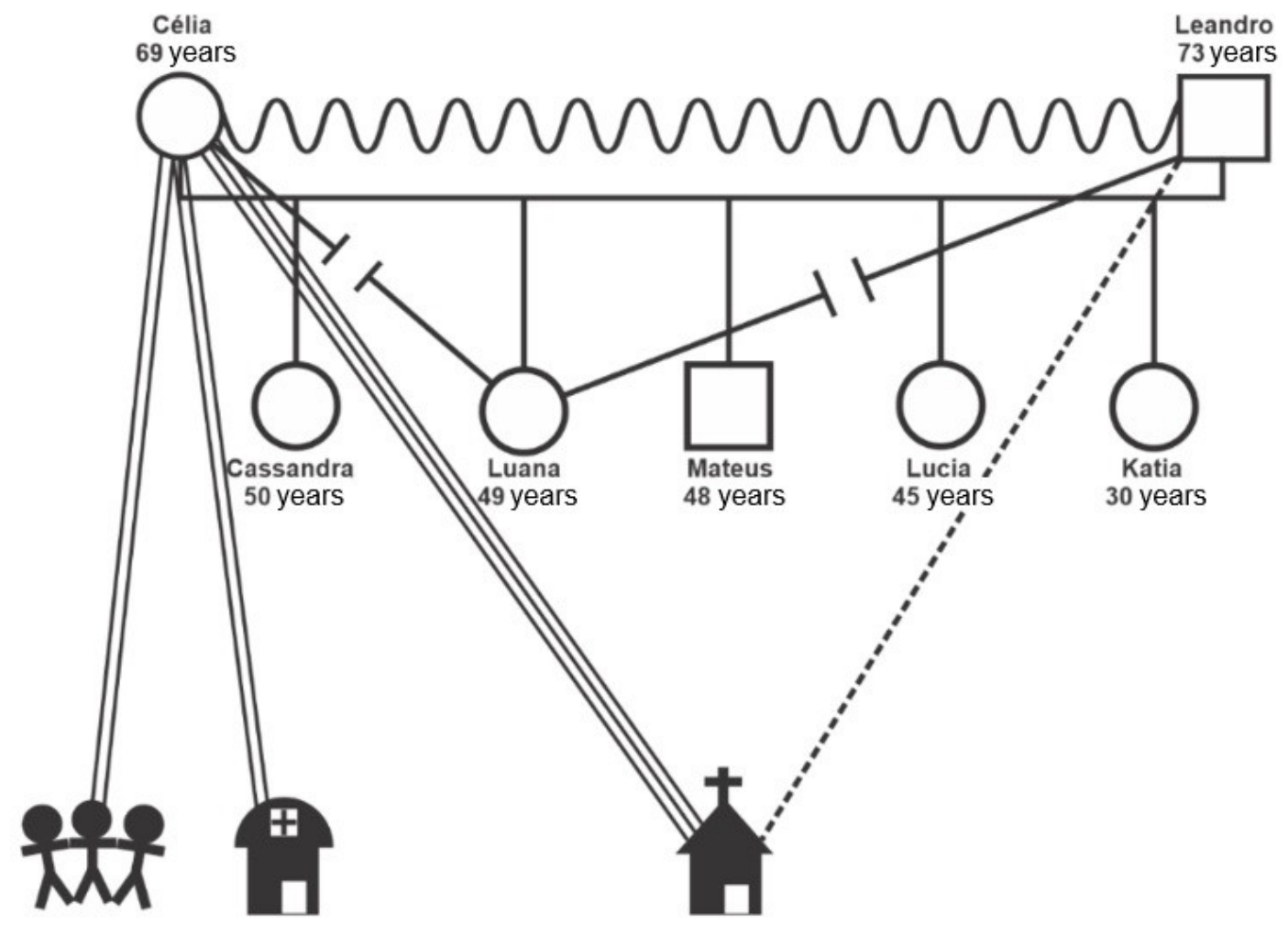

\section{Legend:}

\begin{tabular}{|c|c|c|c|c|}
\hline$\square$ Men & Neighborhood & $\sqcup$ Marriage & -.-- Distant & ユトDisagreemen \\
\hline $\begin{array}{l}\text { Women } \\
\text { We Neighbors }\end{array}$ & $\begin{array}{l}\text { A. Church } \\
\text { BHU }\end{array}$ & $\begin{array}{l}4 \text { Separation } \\
4 \text { Divorce }\end{array}$ & $\begin{array}{l}=\text { Close } \\
\equiv \text { Narrow }\end{array}$ & MV Conflict \\
\hline
\end{tabular}

Figure 1 - Genogram and ecomap of Family 1. Marília-SP-Brazil, 2019

Source: Research data, 2019.

but paid a small monthly installment, the source of income coming from the sick pay that Maria Rita received. Both with incomplete elementary education. Maria Rita mentioned that she was pre-diabetic, depressive and had asthmatic bronchitis, she was using two anti-hypertensive drugs: Nifedipine and Losartan; Clonazepam, inhalation with Atrovent, when she was able to buy it, but normally she used only the serum and did not use the prescribed "pump", due to lack of financial conditions. Maria Rita was excessively skinny, was eating in small quantities and had little variety on the menu, had difficulty walking and sleeping due to lack of air.

The couple had only one son, who was married, and four grandchildren. According to Adelmo, the son did not interfere in conflicts, he visited them from time to time, quickly, and the grandchildren never. Maria Rita had sisters who lived in another city, but she claimed that she didn't ask for help so as not to bother them. The couple had a conflicting relationship and Maria Rita filed the complaint at the women's police station, she reported suffering violence, mostly verbal and psychological, however, she had already been physically attacked a few times and threatened with death, which, according to her, was due to mainly the abusive use of alcohol by the husband. Adelmo, contrary to his wife, pointed out that the reason for the couple's conflict was due to Maria Rita financing all the expenses of the house and blaming him for hiding the rest of the money that his wife hid around the house. Whenever Adelmo went out alone, it caused a feeling of anxiety and agitation in Maria Rita, as she knew that her friends would offer him alcoholic drinks, and with that, he would arrive home altered. Adelmo, on the other hand, felt indignant and claimed that he rarely used alcohol. 
Maria Rita stated that she attended the BHU regularly, accompanied by her husband, due to the illnesses she presented. However, Adelmo claimed that Maria Rita used the medications irregularly and constantly needed to be taken to the ECU. The couple did not attend church because Maria Rita could not stand to walk and Adelmo wouldn't leave her alone at home. Maria Rita had the support of neighbors, especially when she needed to go to the hospital due to lack of air.

Adelmo stated that he was Maria Rita's only caregiver and companion. Both performed household activities together, dividing the tasks, as Adelmo pointed out that he was afraid to leave his wife alone, as she forgot the gas on and did not pay attention to what she was doing. She had difficulties to buy food as she spent money on medication too. Adelmo stated that he was unable to work because he needed to provide care for his wife who was sick. Family 2, represented in Figure 2, shows the structure of Maria Rita's Family.
In Family 3, only Aline was interviewed, who revealed information about Eduardo. The elderly, 69 years old, retired, with income a little more than one minimum wage per month, completed elementary school, married for five years to Eduardo, 60 years old, incomplete elementary school and self-employed. Aline was hypertensive, had diabetes, hypothyroidism and labyrinthitis, used vasopril, atensin, nifedipine, bisoprolol hemifumarate and hydrochlorothiazide for blood pressure, puran, predinisone, amitriptyline hydrochloride, clonazepam, ranitidine, insulin and regular insulin and a drug for labyrinthitis she was unable to inform. Eduardo, in turn, was on dialysis for many years, until he got a kidney transplant, which was done four years ago, and used only the immunosuppressant Tacrolimus.

At the time of the interview, Aline lived alone, as she had a protective measure against her husband. The elderly woman reported that she had a conflicting relationship with her husband, due to verbal abuse, devaluing her as a woman,

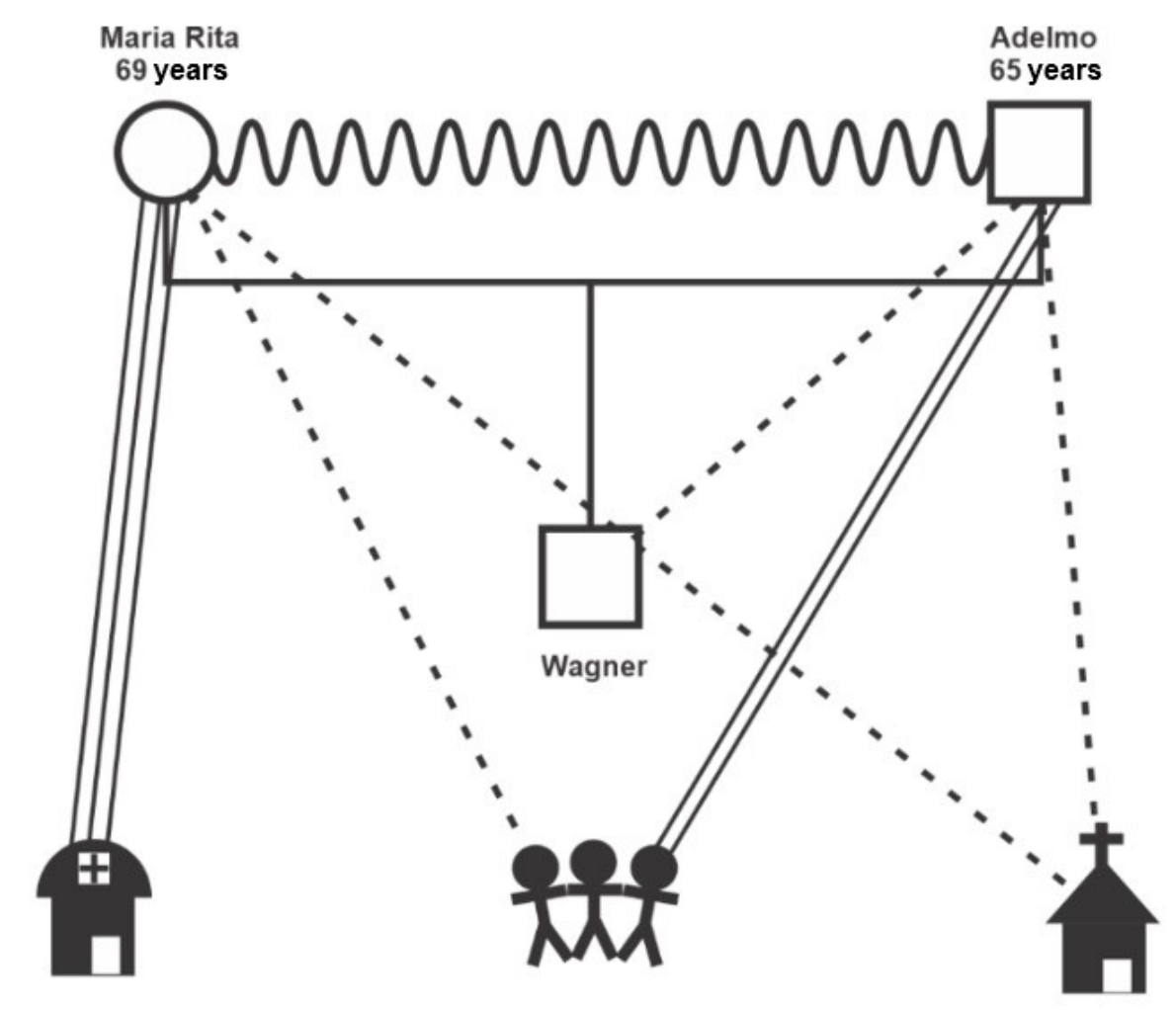

Legend:

\begin{tabular}{|c|c|c|c|c|}
\hline$\square$ Men & Nel Neighborhood & $\sqcup$ Marriage & .... Distant & નト-Disagreement \\
\hline Women & A Church & 丩 Separation & $=$ Close & N Conflict \\
\hline 果 Neighbors & P BHU & I Divorce & $\equiv$ Narrow & \\
\hline
\end{tabular}

Figure 2 - Genogram and ecomap of Family 2. Marília-SP-Brazil, 2019

Source: Research data, 2019. 
in addition to disrespecting her by speaking and praising other women, which caused a feeling of deep sadness in the elderly woman. He also did not collaborate with the household finances, not even for the purchase of food. For this reason, the child from another marriage did not accept the couple's relationship. Aline also had conflict with the son, claiming that her daughter-in-law did everything to keep him away.

The complaint was made by Aline, due to a fight between the son and Eduardo, and after this fact, the son made threats that she would never see him again, nor the grandchildren, if she continued to live with Eduardo, which left her scared and insecure.

After the protective measure against Eduardo, the son and daughter-in-law remained more present and insisted that it was the best thing the mother did, with that, she was not free to carry out her own wishes in relation to her husband, as she reported that she still felt affection for him and worried to see him far away. However, even with the distance, they continued to communicate over the phone and maintained their disagreements.

Aline reported that she had a close relationship with the $\mathrm{BHU}$, as she needed care and medication due to diabetes and hypothyroidism. She reported that she attended the evangelical church every week and participated weekly in gymnastics provided in the neighborhood where she lived. Her relationship with the neighborhood was lost over time due to their change. Family 3, represented in Figure 3, shows the structure of Aline's Family.

Family 4 was composed by Andressa who was 65 years old, retired, having completed elementary school, with two children from her first marriage who did not live with her. The daughter Vanessa resided in the same city as her mother, with whom she had no good relationship, and son Valdeir resided in another city. Andressa was married and lived for 18 years with Norberto, 72 years old, incomplete elementary

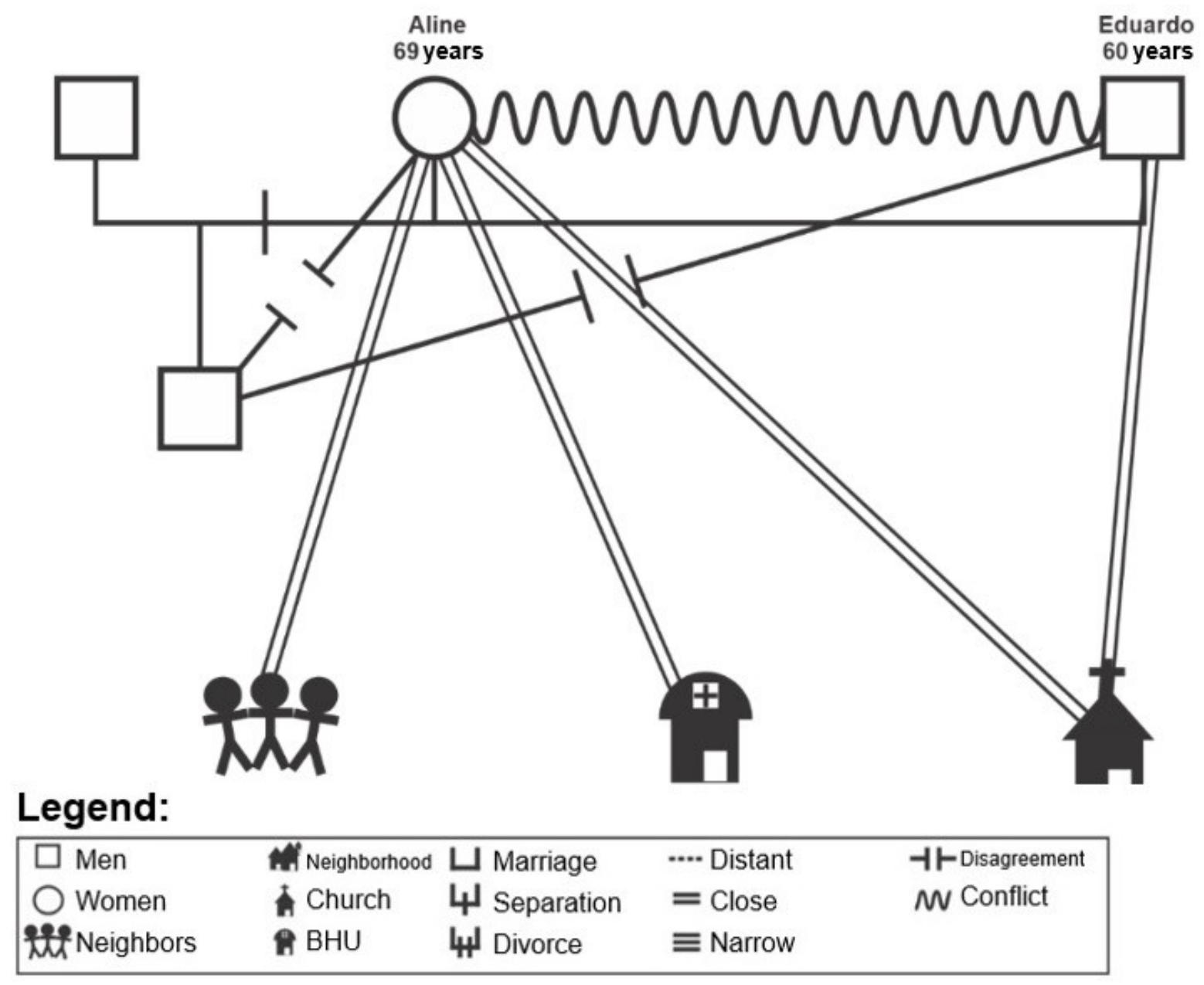

Figure 3 - Genogram and ecomap of Family 3. Marília-SP-Brazil, 2019 Source: Research data, 2019. 
school, retired and three children from another relationship, being an adopted daughter whom she had greater contact and good relationship, with the other sons she had a more distant relationship, as they lived far away too. The couple's income was two minimum wages, in addition, Andressa was also busy making bread and biscuits to sell, and her husband did some bricklaying. They lived in their own house.

The elderly woman had a diagnosis of breast cancer, hypertension, anxiety and calcified neurocysticercosis that caused convulsive crises. She was using phenobarbital and carbamazepine, fluoxetine, anastrozole, enalapril and chloran. She also reported a conflicting relationship with her husband, as he was very aggressive, and she, due to the chemotherapy treatment, had become very nervous and agitated, so any situation was already a reason for her to destabilize.

Norberto reported having arterial hypertension. During the interview, he was calm and said little, stressed that his feeling was of sadness for everything that was happening, because after his wife's illness, her behavior changed a lot. The main reason for conflicts between the Andressa and Norberto case, the creation of five domestic animals by the elderly, which, according to the elderly, was a financial and time expense. Andressa still took care of stray animals at the gate, which also generated conflict with neighbors.
Andressa claimed that animals were important to her life and made her happy.

Andressa informed that the housework was carried out by her, feeling, therefore, overloaded, which also triggered fights in the couple's life, as she was undergoing chemotherapy, there were days when she was not willing. The couple played keyboards at church and attended regularly. In addition, they effectively participated in the neighborhood association and maintained bonds with the health services.

She also narrated that she was angry with her husband, since he did not understand the irritability and anxiety that she had been suffering, resulting from cancer and treatment.

Norberto filed the complaint at the police station, because, after a discussion about housework not performed by him, Andressa pushed him with a squeegee, and he reacted by going on top of her and biting her.

The economic condition was one of the causes that kept the marriage, even after the violence, because they understood that separated, they would have difficulties to survive. Family 4, presented in Figure 4, shows the structure of Andressa's Family.

In view of the above, the strengths and weaknesses that emerged from the assessments of the families of elderly victims of violence were listed, according to Chart 1.

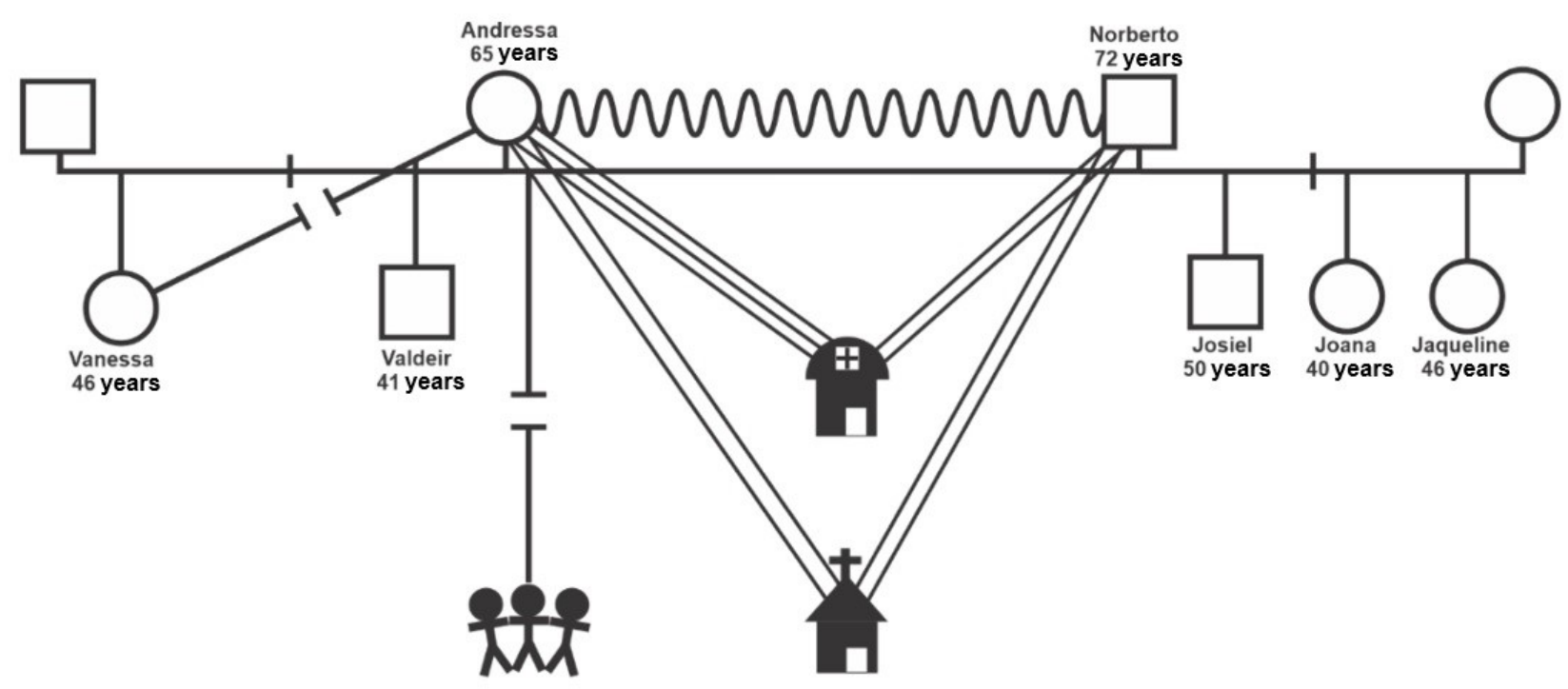

Legend:

\begin{tabular}{|c|c|c|c|c|}
\hline$\square$ Men & Neighborhood & $\sqcup$ Marriage & .... Distant & નト-Disagreement \\
\hline Women & Â Church & 4 Separation & $=$ Close & M Conflict \\
\hline ำ Neighbors & ค $\mathrm{BHU}$ & 4 Divorce & $\equiv$ Narrow & \\
\hline
\end{tabular}

Figure 4 - Genogram and ecomap of Family 4. Marília-SP-Brazil, 2019 Source: Research data, 2019. 


\begin{tabular}{|c|c|c|}
\hline Families & Strengths & Weaknesses \\
\hline 1. & $\begin{array}{l}\text { Religiousness; } \\
\text { Good relationship with sons; } \\
\text { Good integration with neighbors; } \\
\text { Recognition that living together they } \\
\text { could support themselves financially. }\end{array}$ & $\begin{array}{l}\text { Conflict between the couple enhanced by a daughter; } \\
\text { Report of alcohol abuse; } \\
\text { Denial of alcohol use; } \\
\text { Feeling angry and feeling impotence; } \\
\text { Lack of bond with the Health Unit; } \\
\text { Feeling of overload with housework; } \\
\text { Non-adherence to treatment; } \\
\text { Report of deep sadness; } \\
\text { Little contact with sons; } \\
\text { Verbal aggression, with death threat; } \\
\text { Low schooling. }\end{array}$ \\
\hline 2. & $\begin{array}{l}\text { Strong bond with the health unit; } \\
\text { Moderate bond with neighbors; } \\
\text { Responsibility for care. }\end{array}$ & $\begin{array}{l}\text { Conflict between the couple due to financial conditions; } \\
\text { Report of alcohol abuse; } \\
\text { Denial of alcohol use; } \\
\text { Distant relationship with the son; } \\
\text { Difficulty of the wife in adhering to treatments; } \\
\text { Eating in small amounts, leading to weight loss; } \\
\text { Unemployment; } \\
\text { Low income; } \\
\text { Frailty in Maria Rita's health status; } \\
\text { Low schooling. }\end{array}$ \\
\hline 3. & $\begin{array}{l}\text { Religiousness; } \\
\text { Strong bond with the Health Unit; } \\
\text { Participation in gym activities; } \\
\text { Good integration with neighbors. }\end{array}$ & $\begin{array}{l}\text { Unfavorable financial conditions; } \\
\text { Feeling of fear and insecurity regarding the son's threats; } \\
\text { Concern for the distant husband; } \\
\text { Multiple illnesses and use of multiple medications; } \\
\text { Low schooling. }\end{array}$ \\
\hline
\end{tabular}

Chart 1 - Strengths and weaknesses of families nuclei 


\begin{tabular}{|c|c|c|}
\hline Families & Strengths & Weaknesses \\
\hline 4. & $\begin{array}{l}\text { Religiousness; } \\
\text { Moderate bond with the Health Unit; }\end{array}$ & $\begin{array}{l}\text { Conflicting relationship between the couple, due to the } \\
\text { raising of animals by the wife; } \\
\text { Difficulty in relationship to neighbors; } \\
\text { Nervousness of the wife, due to treatment; } \\
\text { Feeling of overload in relation to housework; } \\
\text { Use of multiple medications; } \\
\text { Low schooling. }\end{array}$ \\
\hline
\end{tabular}

Chart 1 - Cont

Source: Research data, 2019

Chart 1 presents the strengths and weaknesses of elderly couples. As for the weaknesses, alcohol abuse was found in the families of Célia and Maria Rita; unfavorable financial conditions and, as a consequence, one depends on the other for survival. The presence of chronic diseases, use of multiple medications, non-adherence to treatment and fragile health conditions were also highlighted. In addition, they expressed different feelings arising from the conflict between the couple (fear, insecurity, anger, nervousness, sadness and impotence). Still, the members of the families were identified with low schooling. As for strength, most were religious and had bonds with the Health Unit.

Following the Calgary Model, the intervention phase consisted of circular questions, which had the objective of triggering changes in three domains: cognitive, affective and behavioral. In the first, the intention was to offer new ideas, opinions, beliefs, information or education about a particular health problem or risk. As for the second domain, an attempt was made to reduce or intensify intense emotions that could harm the solution of the families' problems. In the third domain, it was sought to help the couple to interact and behave differently in relation to each other. Thus, interventions were essentially based on conflict mediation. In the case of Ms. Maria Rita, a severe case of asthmatic bronchitis, the researchers went to the Health Unit, in order to request follow-up more frequently. In addition, Célia was referred to the Psychosocial Care Center due to her deep sadness.

\section{DISCUSSION}

The study contributes to reflections about the reality of elderly couples who, after their sons leave home, start to live daily with their partner and to depend financially on each other, starting to live under family conflicts that affect their healthy survival.

When analyzing the structure of the four families, similar aspects were observed between them and some specificities, inherent to the context of life.

As for schooling, couples with few years of schooling were observed, a characteristic that reflects the national reality, as they spent their childhood in a period when most lived in rural areas and access to school was difficult. Specifically, among the elderly, low educational level predisposes to unfavorable economic conditions, as they have been in the informal market throughout their lives, with no investment possibilities to guarantee retirement ${ }^{(8)}$.

It was found that the elderly in this study had pensions and sick pay as their income, thus corroborating a study that emphasizes that retirement, pensions and government benefits are the main sources of income and support for the elderly in the Brazilian population ${ }^{(9)}$.

Other characteristics among the majority of the elderly in this study were the presence of chronic diseases and the use of multiple medications, which demand actions to promote and prevent injuries carried out by a multidisciplinary team, with the inclusion of the family, since the proper management of this condition it is coated with complexity, whose success is multifactorial. In this perspective, it is highlighted that living at home with the family is strongly related to psychosocial health ${ }^{(10)}$. The elderly women in this study, although living with their partner and who provided care, in case of need, the relationship difficulties prevented a good condition of life, especially in the psychological aspect, which interfered in the treatment of diseases and the use of medications. 
In three cases, only the elderly couple lived in the house and, in one case, the elderly woman lived alone, due to the request for protective measures. It was observed that the causes of the conflicts were, essentially, changes in behavior, due to the use of alcoholic beverages, financial issues, and the division of household chores.

Regarding the feeling of overload in relation to housework, it was noticed that the exercise of this role affected the perception of affection in family relationships, especially in relation to the spouse. The expectation of being cared for was also linked to the experiences lived throughout the relationship, thus, elderly people who did not exercise affection along this path showed less expectation in relation to being cared for by their spouse ${ }^{(11)}$.

It is emphasized that domestic activities and the role of family caregiver were historically attributed to women and are based on cultural and social values of the first half of the last century, in which women assumed the role of household, therefore, they would not need to study ${ }^{(12)}$. Thus, in the minds of their partners, this function is still her attribution, and at this stage of life, as observed in the families analyzed, they no longer had the physical and emotional condition necessary for this function.

It is important to highlight that the occurrence of conflicts, over time, can increase in old age, to the detriment of the high level of demand, impatience and even the possible process of dementia or mental illness that is not understood by family members ${ }^{(13)}$.

Two families in the studies had problems with their partner's alcohol abuse. The abusive use of alcohol and other drugs in old age can be identified as a reflection of retirement, loss of relatives and close friends, hospital admissions or stressful situations. It is understood that alcohol is used to block loneliness, relax, stimulate or even relieve pain. And, as a consequence of the excessive use of alcohol in old age, conflicts between spouses are observed, resulting in physical and verbal aggression, in addition to triggering aggressiveness ${ }^{(14)}$.

It is understood that the perception about the quality of the marital relationship is perceived differently between the genders, given that women have a lower perception of benefits in joint life and task overload, unlike men.

The relationship between the family nucleus and the adult sons/daughters changes over time, as noted in this study, since they constitute their own families and move away from their parents. It is also known that many elderly people refuse, despite often needing, the help of their children or even interpret it as unnecessary, resulting in future problems in family life and creating other types of conflicts ${ }^{(15)}$.
In the four families studied, it was understood that the family institution was transformed several times, with the growth of children, who, as a consequence, creating other family nucleus, being the most significant effect of change. The idea of a nuclear family, composed of father, mother and children, is no longer a model. However, the family continues to play an essential role in the lives of individuals, generating identity, language, culture and care ${ }^{(6)}$.

At the time of the interview, except for Aline, the family typologies were the same, that is, the nucleus consisted only of the elderly couple. The four women suffered some type of violence by their husbands, however, in one of the cases, one of the husbands chose to file a complaint at the police station.

Gender violence is the expression of patriarchy and sexism, as cultural values are associated with inequalities, and violence establishes the 'naturalness' of differences, with stereotypes and codes of conduct between men and women. It was evidenced, therefore, that it is in the family environment that gender violence is most persistent, affecting female subjectivity. It is presented as an expression to refer to the various acts committed against women, as a way of subjecting them to physical, sexual, and psychological suffering, including the various forms of threats. It is characterized, especially, by the imposition or pretension of subordination and the control of male over female gender ${ }^{(16)}$.

In old age, the model of masculinity that values the control of emotions, sexism and competitiveness tend to be exacerbated, as the elderly loses command functions and, thus, is relegated to a secondary position. This feeling usually makes them feel useless, incapable and humiliated, because of this, sexism is more evident in the daily life of this elderly person, so that they can show that they still have control over the whole situation ${ }^{(17)}$.

Another factor observed and not studied was religiousness, which proved to be a strength in family contexts, as it collaborates with psychological strengthening. Religiousness is associated with functional capacity, coping with incapacity and delaying functional decline in the elderly. Different aspects of religiousness were associated with functional capacity, such as participation in religious activities, holding a position of religious leadership, beliefs and religious traditions ${ }^{(18)}$.

Social networks made up of friends also contribute to the quality of life of the elderly, more than family networks, however, it is also shown that more than one type of relationship, family and friendship, favors this same quality for this same audience ${ }^{(19)}$.

In order to resolve conflicts in the marital context, strategies must be used by couples, such as talking peacefully, 
evaluating the consequences of what can be said or done, and remaining calm, regardless of the situation. Other procedures that can be used, such as writing down thoughts before saying them, in order to filter out feelings and rethink what can be said, realize when to step back on a discussion, take a stand in the face of conflicts and, above all, respect the partner. In addition to these, other dynamics can be used after periods of marriage, since the subjective characteristics of the partner are known, avoiding reasons for other conflicts and other conflicting situations ${ }^{(20)}$.

\section{finAl CONSIDERATIONS}

Through the Calgary Model, four families of elderly victims of violence were assessed, highlighting, in their structure, development and functioning, weaknesses and potentialities that must be considered in the elaboration of the care plan. As for weaknesses, it was found alcohol abuse; unfavorable financial conditions and, as a consequence, one depends on the other for survival; presence of chronic diseases; use of multiple medications; non-adherence to treatment; and fragile health conditions. In addition, they expressed feelings of fear, insecurity, anger, nervousness, sadness, and impotence, resulting from the conflict between the couple. Still, the members of the families were identified with low schooling. With regard to potentialities, most were religious and had bonds with the Health Unit.

It was found that only the elderly couple lived in the same household, who despite being mutually dependent for health care and economic issues, could not maintain a harmonious relationship, which interfered with the quality of life, due to their vulnerability to the health conditions.

Interventions with family members were carried out according to the needs of each one of them and essentially involved conflict resolution strategies. Thus, it is revealed the importance of actions aimed at improving the functioning of families of elderly victims of violence, as they are in a stage of life whose needs become more frequent and intense, the maintenance of affective bonds and support mutual benefit can contribute to an improvement in the quality of life and sense of well-being.

The study had as limitation the fact that it was performed only with elderly victims of violence who filed a complaint at the police station and that going to their homes did not represent a risk to the researchers. Therefore, it is possible that elderly people with greater vulnerabilities have not been assessed. Despite this fact, the study provided reflection on the theme and the possibilities of developing future investigations that intend to provide comprehensive care to families.
It is expected to contribute to the sensitization of nursing professionals on the importance of using the Calgary Family Assessment Model, for better performance in the face of the needs of families of elderly victims of violence, as the model provides guidance for the development of actions in line with the complexity that this condition represents.

\section{Q REFERENCES}

1. Souza EDA. Perfil de morbimortalidade e os desafios para a atenção domiciliar do idoso brasileiro. Rev Kairós Gerontol. 2017;20(1):93-108. doi: https://doi. org/10.23925/2176-901X.2017v20i1p93-108

2. Santos FS, Saintrain MVL, Vieira LJES, Sampaio EGM. Characterization and prevalence of elder abuse in Brazil. J Interpers Violence. 2021;36(7-8):NP3803NP3819. doi: https://doi.org/10.1177/0886260518781806

3. Ministério da Saúde (BR). Secretaria de Vigilância em Saúde. VIVA: Vigilância de Violências e Acidentes: 2013 e 2014. Brasília: Ministério da Saúde; 2017 [cited 2020 Apr 10]. Available from: https://bvsms.saude.gov.br/bvs/publicacoes/ viva_vigilancia_violencia_acidentes_2013_2014.pdf

4. Cecilio HPM, Santos KS, Vendrameto MM, Marcon SS. Calgary Model Of Family Assessment: experience in a community service project. Cogitare Enferm. 2014;19(3):493:501. doi: https://doi.org/10.5380/ce.v19i3.32729

5. Silva CFS, Dias CMSB. Violência contra idosos na família: motivações, sentimentos e necessidades do agressor. Psicol Cienc Prof. 2016; 36(3): 637-52. doi: https:// doi.org/10.1590/1982-3703001462014.

6. Costa SFG, Oliveira RC, Zaccara AAL, Souza AFM, Gomes BMR, Oliveira TC. The use of Calgary model in nursing dissertations: and theses: a bibliometric study. Rev Pesqui Cuid Fundam Online. 2018;10(4):1156-63. doi: https://doi. org/10.9789/2175-5361.2018.v10i4.1156-1163

7. Wright LM, Leahey M. Enfermeiras e famílias: um guia para avaliação e intervenção na família. 5. ed. São Paulo: Roca; 2012.

8. International Longevity Centre Brazil. Active aging: a policy framework in response to the longevity revolution [Internet]. Rio de Janeiro: ILC-Brazil; 2015.

9. Wendt CJ, Aires M, Paz AA, Fengler FL, Paskulin LM. Elderly families in South of Brazil in Health Strategy. Rev Bras Enferm. 2015;68(3):350-7. doi: https://doi. org/10.1590/0034-7167.2015680305i

10. Zulfitri R, Sabrian F, Herlina. Sociodemographic characteristics and psychosocial wellbeing of elderly with chronic illnesses who live with family at home. Enferm Clín. 2019;29 Suppl 1:34-7. doi: https://doi.org/10.1016/j.enfcli.2018.11.014

11. Silva LLNB, Rabelo DF. Afetividade e conflito nas díades familiares, capacidade funcional e expectativa de cuidado de idosos. Pensando Fam. 2017 [cited 2020 Feb 10];21(1):80-91. Available from: http://pepsic.bvsalud.org/scielo. php? script=sci_arttext\&pid=\$1679-494X2017000100007\&lng=pt\&nrm=iso

12. Carvalho EB, Neri AL. fTime use by family caregivers of elderly with dementia: na integrative review. Rev Bras Enferm. 2018;71 Suppl 2:893-904. doi: https:// doi.org/10.1590/0034-7167-2017-0268

13. Silva CFS, Dias CMSB. Violência contra idosos na família: motivações, sentimentos e necessidades do agressor. Psicol Cienc Prof. 2016;36(3):637-52. doi: https:// doi.org/10.1590/1982-3703001462014

14. Azevedo LN, Souza LMP, Silva Junior RF, Durães LE, Oliveira CS, Arcanjo IN. Alcoolismo na terceira idade: revisão literária [Internet]. Rev EFDeportes.com. 2016 [cited 2020 Feb. 11];20(214). Available from: https://www.efdeportes. com/efd214/alcoolismo-na-terceira-idade.htm 
15. Rabelo DF. Os idosos e as relações familiares. In: Freitas EV, Py L. Tratado de geriatria e gerontologia. Rio de Janeiro: Guanabara Koogan; 2016. p. 1515-25.

16. Balbinotti I. A violência contra a mulher como expressão do patriarcado e do machismo. Rev ESMESC. 2018;25(31):239-64. doi: https://doi.org/10.14295/ revistadaesmesc.v25i31.p239

17. Medeiros PA, Streit IA, Sandreschi PF, Fortunato AR, Mazo GZ. Participação masculina em modalidades de atividades físicas de um programa para idosos: um estudo longitudinal. Ciênc Saúde Coletiva. 2014; 9(8):3479-88. doi: https:// doi.org/10.1590/1413-81232014198.16252013
18. Amorim DNP, Silveira CML, Alves VP, Faleiros VP, Vilaça KHC. Association between religiosity and functional capacity in older adults: a systematic review. Rev Bras Geriatr Gerontol. 2017;20(5):722-30. doi: https://doi. org/10.1590/1981-22562017020.170088

19. Gouveia OMR, Matos AD, Schouten MJ. Social networks and quality of life of elderly persons: a review and critical analysis of literature. Rev Bras Geriatr Gerontol. 2016;19(6):1030-40. doi: https://doi.org/10.1590/1981-22562016019.160017

20. Costa CB, Mosmann (P. Estratégias de resolução dos conflitos conjugais: percepções de um grupo focal. Psico. 2015;46(4):472-82. doi: https://doi. org/10.15448/1980-8623.2015.4.20606 
- Funding/ Acknowledgment:

Coordination for the Improvement of Higher Education Personnel (Coordenação de Aperfeiçoamento de

Pessoal de Nível Superior - CAPES); São Paulo Research

Foundation (Fundação de Amparo à Pesquisa do Estado

de São Paulo - FAPESP) process no. 2017/17562-2.

\section{- Authorship contribution:}

Conceptualization: Miriam Fernanda Sanches Alarcon, Bruna Carvalho Cardoso, Caroline Borges Ala, Daniela

Garcia Damaceno, Viviane Boacnin Yoneda Sponchiado, Maria José Sanches Marin.

Data curation: Miriam Fernanda Sanches Alarcon, Bruna Carvalho Cardoso, Caroline Borges Ala.

Formal analysis: Miriam Fernanda Sanches Alarcon, Daniela Garcia Damaceno, Maria José Sanches Marin.

Funding acquisition: Maria José Sanches Marin, Miriam Fernanda Sanches Alarcon.

Investigation: Miriam Fernanda Sanches Alarcon, Bruna Carvalho Cardoso, Caroline Borges Ala.

Methodology: Miriam Fernanda Sanches Alarcon, Bruna Carvalho Cardoso, Caroline Borges Ala, Daniela Garcia

Damaceno, Viviane Boacnin Yoneda Sponchiado, Maria José Sanches Marin.

Project administration: Miriam Fernanda Sanches

Alarcon, Maria José Sanches Marin.

Supervision: Miriam Fernanda Sanches Alarcon, Maria José Sanches Marin.

Writing-original draft: Miriam Fernanda Sanches

Alarcon, Bruna Carvalho Cardoso, Caroline Borges Ala,

Daniela Garcia Damaceno, Viviane Boacnin Yoneda

Sponchiado, Maria José Sanches Marin.

Writing-review \& editing: Maria José Sanches Marin,

Miriam Fernanda Sanches Alarcon.

The authors declare that there is no conflict of interest.

\section{- Corresponding author:}

Miriam Fernanda Sanches Alarcon

E-mail: miriam@uenp.edu.br

\section{Associate editor:}

Jéssica Machado Teles

Editor-in-chief:

Approved: 04.06.2021
Maria da Graça Oliveira Crossetti 